\title{
ДОСЛІДЖЕННЯ УРБАНІСТИЧНОГО ВПЛИВУ НА ТЕРИТОРІЮ СМТ. ОЛИКА
}

\section{URBAN INFLUENCE RESEARCH ON THE TERRITORY OF OLYKA VILLAGE}

\begin{abstract}
Парфентьєва І. О. к.т.н., доц., Мельник Ю.А., к.т.н., доц., Гурик М.Ю., магістр, Яйченя В.П., магістр, Ляшук С.В., студент 4 курсу (Луцький національний технічний університет)
\end{abstract}

Parfenteva I.O., Ph.D. in Engineering, Associate Professor, Melnyk. Yu.A., Ph.D. in Engineering, Associate, Huryk M.Yu., MSc, Yaichenia. V. P., MSc, Liashuk S.V., 4th year student, (Lutsk National Technical University)

Анотація. Проведено аналіз урбаністичного виливу на містобудівну діяльність. Розглянуто перспективи розвитку українських міст та сіл, вплив історичної спадщини, на формування розвитку поселення на прикладі, смт. Олика.

Summary. This article is about the unique special villages of Olyka. For the first time, Olyka is mentioned in the Ipatiev Chronicle of 1149, and the settlement is located in the Volyn region at the intersection of roads from the cities of Dubno, Rivne and Lutsk. Not in the corner of Olyka's historical monuments - the entrance gates, the castle, the collegium, the town hall. They rise above the hills of the village, showing the great disadvantages. Repeatedly research, cultural and historical heritage of the area has been carried out. At present the settlement is included in the list of historical settlements of Ukraine, approved by the Resolution of the Cabinet of Ministers of Ukraine of July 26, 2001. 878. Olyka is a historically enriched place, a center that combines landmarks of architecture. It is the historical sites that make this place unique and emphasize its uniqueness. The main purpose of this work is the development plan of the village Olyka, which is to promote the historical heritage in combination with modern living conditions, which will attract tourists to this area. A comprehensive analysis of the village of Olyka was carried out, which included schemes on all aspects of activity, existence and life in general; allows you to identify the necessary priorities for the development of the settlement. Creating functional area maps shows a clear separation of existing and required objects. Using functional zoning Olyka villages were identified and analyzed the large number of water resources; possibility of settlement development; a large number of historical monuments; industrial and residential area. Organizing interesting leisure, highlighting the features and values of the village, creating comfortable amenities will emphasize the uniqueness of the village Olyka.

Ключові слова: містобудування, аналіз, урбаністика, дослідження.

Keywords: urban planning, analysis, urbanization process, research. 
Постанова проблеми. Місто чи село, мегаполіс чи невеликий хутір це живий організм, який постійно потребує модернізації та змін. Для того, щоб зрозуміти, що саме потрібно місту чи селу, необхідно зробити урбаністичний та містобудівний аналіз. В даному випадку це селище міського типу Олика.

Аналіз відомих досліджень і публікацій. Згадка про невелике поселення Олика з'являється ще Іпатіївському літописі під 1149 роком. Селище, що у Волинській області, знаходиться на перетині доріг 3 міст Дубно, Рівного і Луцька, утворивши своєрідний вузол на шляху з Азії у країни Західної Європи, що у минулому сприяло торговельним відносинам і зростанню його оборонного значення [1].

Протягом чотирьох століть у містечку господарювала династія Радзивілів. Чи не у кожному куточку Олики історичні пам'ятки - в'їзні ворота, замок, костел-колегіата, ратуша. Вони височіють над пагорбами селища, щодня нагадуючи про величне минуле [2].

«Оригінальна кладка, перевірена століттями. Жоден асфальт не зрівняється 3 цією старовинною технологією. А вібрації під колесами створюють цілу мелодію. Чим не волинський тунель кохання?» - ділиться думками депутат Волинської обласної ради Олександр Омельчук [3].

Неодноразово були проведенні дослідження культурної та історичної спадщини даної території, тут знаходяться і старовинні архітектурні споруди, як оборонного, так і сакрального зодчества, і порослі полином кургани, а історія цього містечка княжої доби оповита таїною давніх переказів і легенд.

На даний час селище внесено до списку історичних населених місць України, затвердженого постановою Кабінету Міністрів України від 26 липня 2001 р. № 878 [4].

Мета статті: аналіз містобудівного стану території, шляхом дослідження генерального плану; створенням детальних схем та виокремленням функціональних зон; розвиток даного поселення шляхом підкреслення особливостей селища, перспективи розвитку в туристичній сфері, шляхом покращення умов життя жителів, на фоні отриманих при містобудівному аналізі досліджень.

\section{Завдання:}

- необхідно провести аналіз території даного селища міського типу та дослідити його 3 позицій формування історико-культурної спадщини, розвитку житлової інфраструктури, торгівельної, промислової;

- розробити план розвитку смт. Олики, як центру історичного та культурного відпочинку;

- запропонувати варіант створення цікавого, пізнавального та комфортного місця відпочинку. 
Аналіз існуючого стану. Як правило, містобудівний аналіз починається 3 виявлення розташування ділянки проектування відносно населеного пункту. Від того, чи розташована ділянка у місті, селищі міського типу, селі або ж взагалі за межами населених пунктів, залежать як нормований iї розмір, так і функціональне призначення й склад приміщень об’єкта [2].

Визначення основних характеристик архітектурного об'єкта та планування нового відбувається 3 узгодженням містобудівної документації, зокрема, з генеральним планом та схемою функціонального зонування та на основі ДБН Б.2.2.-12:2019 « Планування і забудова територій».

За [3] генеральний план є головним містобудівним документом, який визначає використання землі в місті: скільки, де і чого будувати: житла, транспортної інфраструктури, промисловості, послуг, офісів чи рекреаційних зон. Він може містити матеріали, які $є$ державною таємницею і недоступні публічно.

Аналізуючи генеральний план смт. Олика, виділяючи функціональне зонування ( рис.1), було виявлено велику кількість руїн, наявність багатьох озер та великої кількості лісів і зелених насаджень.

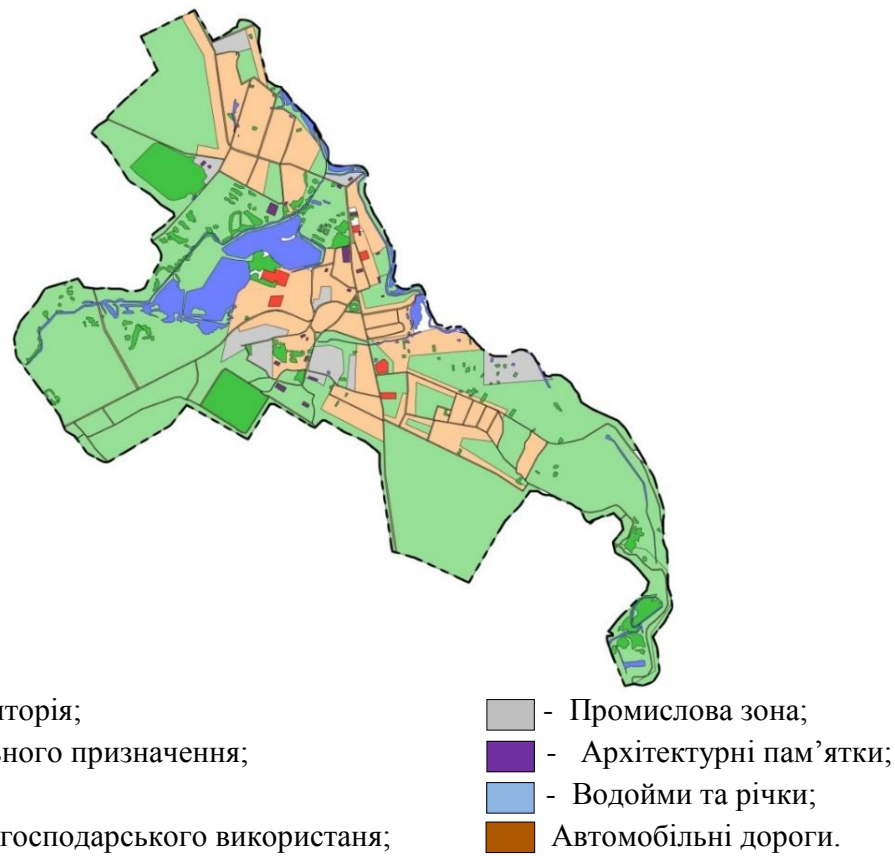

Рис. 1. Функціональне зонування смт. Олика 
Від селища Олика до міжнародної автомагістралі Е85 (М19) Клайпеда - Каунас - Слонім - Луцьк - Дубно - Тернопіль - Чернівці 35 км. До національної автомобільної дороги Н22 Устилуг - Луцьк - Рівне 6 км. У селищі працює автостанція, через яку автобусами та маршрутними таксі здійснюються перевезення Ківерцівським районом, Волинською областю та Україною. Основні вантажопасажирські перевезення здійснюються через залізничну станцію Олика, відстань до якої 11 км [5].

Забудова ділянки переважно однотипна, багатоповерхівки відсутні, максимальна висота забудови - два поверхи. Наявна школа, садочок, будинок культури, міська бібліотека, лікарня.

Олика - історично збагачене місце (рис.2), центр, який об'єднує в собі визначні пам'ятки архітектури. Саме історичні пам'ятки надають особливість цьому місцю та підкреслюють його унікальність.

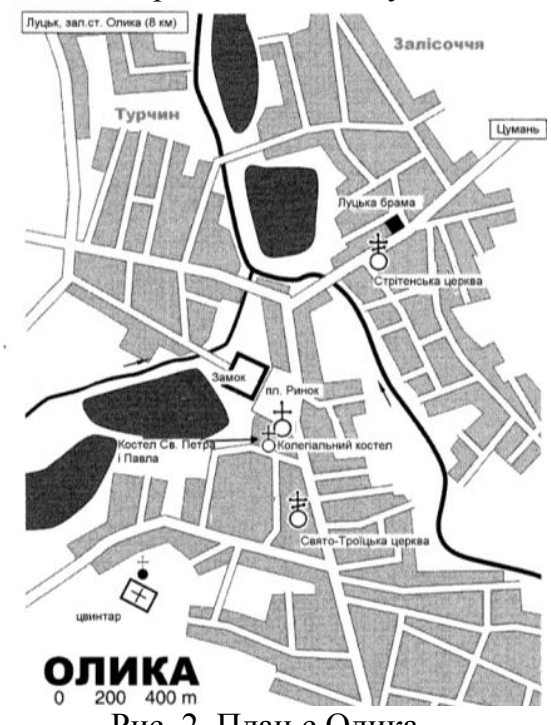

Рис. 2. План с.Олика

На території знаходиться багато полів, які не використовуються в повному обсязі, хоча існують маленькі підприємства та заводи. 3 точки зору містобудівної діяльності та урбаністичного аналізу Олика знаходиться на межі руйнації історичної спадщини. Унікальні пам'ятки історії у критичному стані, потребують реставрації або зміни призначення.

Так наприклад, Олицький замок (рис.3) - перший в Україні прямокутний замок постійного типу, використовується як психіатрична лікарня. Тому основним напрямком або ж стратегію для розвитку селища $\epsilon$ створення цікавого місця для туристів та комфортного життя для населення. 


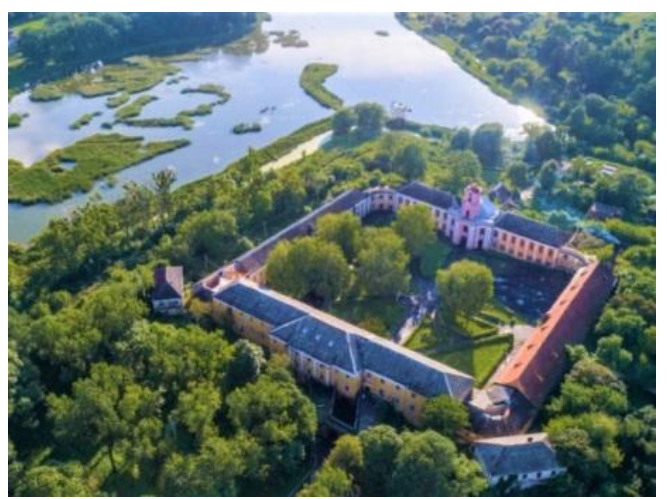

Рис. 3. Олицький замок з висоти пташиного польоту

Пропозиції. Для підкреслення особливостей та покращення статусу смт. Олики потрібно провести такі дії.

1. Відокремити замок та психіатричну лікарню:

- на віддаленій території від центру, в тихій зоні створити лікарню для реабілітації пацієнтів 3 можливістю проживання персоналу.

2. Провести реставрацію всіх можливих пам'яток архітектури:

- за підтримки місцевої влади та органів самоврядування створити групу, що буде сприяти пошуку спеціалістів, залученню спонсорів та контролю якості.

3. Виокремити зони відпочинку та туристичні маршрути:

- за наявності великої кількість ставків, створити зони для відпочинку мешканців та гостей селища, шляхом благоустрою прибережної зони (лавки, освітлення, місця для риболовлі);

- створити туристичні маршрути, карти та цікаві історії селища за допомогою QR-кодів.

4. Модернізація аграрної промисловості:

- засадження полів для імпорту та внутрішнього споживання;

- створення ферм.

5. Створення публічних просторів:

- забезпечення вуличними меблями, спортивними тренажерами, дитячими ігровими елементами; передбачити захист від несприятливих погодних умов: притінені місця у спеку та накриття у дощову погоду;

- доглянута територія, відповідний дизайн;

- для залучення відвідувачів використовувати інсталяції скульптури, проводити фестивалі, ярмарки, роботи відкриті кіноперегляди та майстер класи.

Висновки: Основною ціллю даної роботи є план розвитку селища Олика, який полягає в популяризації історичної спадщини в поєднанні 3 
сучасними умовами життя, що дозволить залучити туристів до даної територї.

Комплексний аналіз, що включає схеми по всіх аспектах діяльності, існування та життя в цілому, дає змогу визначити необхідні пріоритети для розвитку поселення. Створення карт з функціональними зонами показує чітке виокремлення наявних та потрібних об'єктів.

За допомогою функціонального зонування смт. Олика було виявлено та проаналізовано:

- наявність великої кількості водних ресурсів;

- можливість розбудови та розвитку поселення;

- велику кількість історичних пам'ятників;

- промислову та житлову зону.

Організація цікавого дозвілля, виокремлення особливостей та цінностей селища, створення комфортного благоустрою підкреслить унікальність смт. Олика.

\section{References}

1. "Drymba" — ukrayins'kyy turystychno-krayeznavchyy portal [Elektronnyi resurs]. - URL : https://drymba.com/uk/1004864-smt-olyka;

2. Zakonodavstvo Ukrayiny [Elektronnyi resurs]. - URL: https://zakon.rada.gov.ua/laws/show/878-2001-\%D0\%BF;

3. Stattya «Slidamy dynastiyi Radzyvilliv, abo koly Olyka stane turystychnym tsentrom?»[Elektronnyi resurs]. - URL : https://www.hroniky.com/articles/view/144slidamy-dynastii-radzyvilliv-abo-koly-olyka-stane-turystychnym-tsentrom;

4. Mistosite - ukrayins'ka urbanistychna platforma [Elektronnyi resurs]. - URL: https://mistosite.org.ua/ru/articles/shcho-take-urbanistyka-korotka-istoriia-i-shistvyznachen.

5. Parfent'yeva I.O., Osoblyvosti rekonstruktsiyi terytoriyi rynku smt. Olyka v aspekti istoryko-kul'turnoyi spadshchyny /Parfent'yeva I.O., Lyashuk S.V. // materialy III Vseukrayins'koyi naukovo-praktychnoyi internet-konferentsiyi - Syevyerodonets'k: SNU im. V. Dalya, 2019.- 55 s.

\section{Список використаної літератури}

1."Дримба" — український туристично-краєзнавчий портал [Електронний pecypc]. - URL : https://drymba.com/uk/1004864-smt-olyka;

2 Законодавство України [Електронний ресурс]. - URL: https://zakon.rada.gov.ua/laws/show/878-2001-\%D0\%BF;

3 Стаття «Слідами династії Радзивіллів, або коли Олика стане туристичним центром?» [Електронний ресурс]. - URL: https://www.hroniky.com/articles/view/144slidamy-dynastii-radzyvilliv-abo-koly-olyka-stane-turystychnym-tsentrom;

4 Mistosite - українська урбаністична платформа [Електронний ресурс]. URL : https://mistosite.org.ua/ru/articles/shcho-take-urbanistyka-korotka-istoriia-i-shistvyznachen.

5 Парфентьєва І.О., Особливості реконструкції території ринку смт. Олика в аспекті історико-культурної спадщини /Парфентьєва I.О., Ляшук С.В. // матеріали III Всеукраїнської науково-практичної інтернет-конференції - Сєвєродонецьк: СНУ ім. В. Даля, 2019.- 55 с. 